\title{
Hva skal vi med historien?
}

Engelsk oversettelse av hele artikkelen på www.tidsskriftet.no

Årets julenummer inneholder, som tradisjonen tilsier, et knippe medisinhistoriske artikler. I en tid der spalteplass er mangelvare kan det være på sin plass å si noe om hvorfor vi år etter år prioriterer dette stoffet. Hva kan medisinhistorien tilby leger av i dag?

Det er relativt nytt at vi i det hele tatt stiller spørsmål ved historiens nytte. For en lege på begynnelsen av 1800-tallet var «medisinhistoriske» tekster en like naturlig referanseramme som tekster fra hans samtid. Hippokrates, Galen og Vesalius kunne tilby like relevante løsninger på kliniske dilemmaer som samtidens referanseverk og inngikk derfor også i studiet (1). I den første doktoravhandlingen ved det nyopprettede universitetet i Christiania, Frederik Holsts verk om radesyken, brukes kilder fra antikken og renessansen side om side med medisinske skrifter fra hans egen samtid (2). R.T.H. Laënnec, som i ettertid har fătt æren for oppfinnelsen av stetoskopet, begynte karrieren med en avhandling der han lovpriste de hippokratiske skriftenes relevans for den praktiske medisin (1). På denne tiden ble også den kjente aforismen fra det hippokratiske korpus, «kunsten er lang, livet er kort», forstått annerledes enn i dag. Mens vi med legekunst forstår det som ikke er vitenskap i det medisinske møtet - som teknologi og medmenneskelighet - var legekunst da summen av all medisinsk kunnskap. Geoffrey Chaucers 1300-tallsoversettelse er «the lyf so short, the craft so long to lerne» (1).

I løpet av 1800-tallet ble grunnlaget for den moderne medisin lagt. Sykdommene ble forankret lokalt i den enkelte syke kropp, sykehusene ble sentrale medisinske institusjoner, og patologisk anatomi og etter hvert også eksperimentell fysiologi kom til å utgjøre den nye medisinens grunnlag $(3,4)$. De nye teoriene ble ledsaget av stadig nye diagnostiske, forebyggende og terapeutiske redskaper, som mikroskopet, stetoskopet, vaksinasjon, anestesi, antiseptikk og røntgen. Samtidig oppsto det et skille mellom kunst og vitenskap i den medisinske virksomhet. Vitenskapen ble kunnskapsbasen, kunsten var alt det andre man tok i bruk når den skulle appliseres på konkrete pasienter. For den nye vitenskapen hadde fortidens tekster ingen relevans. De ble delegert til i beste fall en samling klassikere, $i$ verste fall et knippe kuriositeter som man kunne konversere om i middagsselskaper.

På slutten av 1800-tallet kom det imidlertid til en protest mot denne utviklingen. Medisinsk historie ble av leger som William Osler oppfattet som et botemiddel mot fragmenteringen og reduksjonismen innen faget og skulle gjøre det lettere for studentene å se medisinen som et hele, i samfunnet (5). Den humanistiske dannelsestradisjonen, og i særlig grad historien, skulle gi legene sans for helheten i den kliniske praksis i en tid der det vitenskapelige fremskritt fordret stadig mer spesialisering og oppsplitting. Medisinen trengte sin historie fordi medisinsk praksis ble bedre av humaniora og kunst. Hundre år etter William Osler er medisinen blitt allemannseie. Ukeblader og aviser er mettet med helsestoff, risikodiskursen forvaltes over middagsbordet og helseturisme er blitt vanlig. Den høyteknologiske medisinen er blitt en del av vanlige menneskers hverdag. Hva skal vi i en slik situasjon med medisinsk historie?

Vi kommer ikke unna historien. Vår individuelle historie - vår livshistorie, våre erfaringer - er med på å forme oss som mennesker. Tilsvarende er den kollektive historien vi alle er del av med på å prege hvordan vi forholder oss til samtidige fenomener. Historien er med på å bestemme hvordan sykehusene er organisert, hvordan profesjonene forholder seg til hverandre, hvordan lege-pasient-forholdet utspiller seg. Medisinhistorien kan vise hvordan vi er kommet dit vi er i dag og løfte frem sammenhengen mellom tidligere tider og nåtiden - og hvilke faktorer som har formet dagens situasjon.

Mye god medisinhistorie har imidlertid vist bruddene og tilfeldighetene i utviklingen, snarere enn sammenhengen (4). Dette gjør det mulig å tenke annerledes også om vår tid. Hvis dagens situasjon $i k k e$ er oppstått på bakgrunn av en stadig fremskridende rasjonalitet, er den verken nødvendig eller uunngåelig. Det kan gi oss et større handlingsrom her og nå. For eksempel har det vært en vanlig oppfatning at 1950-årenes nye medikamenter, som antihypertensiver og kolesterolsenkende midler, ble utviklet som et resultat av ny medisinsk kunnskap. Medisinhistorikeren Jeremy Greene har imidlertid vist hvordan sykdommer som asymptomatisk diabetes, høyt kolesterolnivå, hypertensjon og astma ble konstruert som et betydelig folkehelseproblem samtidig som det kom medisiner på markedet til å behandle dem (6). Ved å vise hvordan forbindelsene mellom markedsføring, folkehelsearbeid og medisinsk praksis ikke fremkommer som et uunngåelig resultat av ny kunnskap, gjør hans forskning det mulig å stille spørsmål ved den medisinske kunnskapens økonomi på nye måter.

Julenummeret skal gi beskyttelse mot historieløsheten (7). Men det er ikke likegyldig hva slags historie som presenteres. Historien vi lager om vår egen fortid, former ikke bare vårt syn på denne. Den er også avgjørende for hvordan vi ser fremover. Forstår vi for eksempel medisinhistorien som en fremskrittshistorie, er vi mer tilbøyelige til å ta de teknologiske fremskrittene for god fisk og som noe som vi med nødvendighet må ta i bruk. Ser vi imidlertid medisinhistorien som en rekke tilfeldige begivenheter, er vi mer tilbøyelige til å sette spørsmålstegn ved dagens teori og praksis. Skal medisinhistorien fungere som et korrektiv til dagens praksis, bør den altså ikke primært være et verktøy for dannelse.

\section{Anne Kreim Lie}

a.h.k.lie@medisin.uio.no

Anne Kveim Lie (f. 1969) er førsteamanuensis i medisinsk historie og medisinsk redaktør i Tidsskriftet.

Ingen oppgitte interessekonflikter.

\section{Litteratur}

1. Huisman F. Warner JH. Locating medical history: the stories and their meanings. Baltimore: Johns Hopkins University Press, 2004.

2. Holst F, Lie AK, red. Hva er sykdommen som kalles Radesyge, og på hvilken måte kan den utryddes fra Skandinavia? med utdrag av Claus Pavels' dagboks notater fra doktordisputasen. Oslo: Det norske medicinske Selskab, 2005.

3. Ackerknecht EH. Medicine at the Paris hospital, 1794-1848. Baltimore: Johns Hopkins University Press, 1967.

4. Foucault M. The birth of the clinic: an archaeology of medical perception. London: Tavistock, 1973

5. Osler W. The principles and practice of medicine: designed for the use of practitioners and students of medicine. Edinburgh: Young J. Pentland, 1901

6. Greene J. Prescribing by numbers. Baltimore: Johns Hopkins University Press, 2007.

7. Nylenna M. Regn med Tidsskriftet. Tidsskr Nor Lægeforen 1995; 115: 3711. 